International Journal of Natural Sciences Research

2022 Vol. 10, No. 1, pp. 1-20.

$\operatorname{ISSN}(e): 2311-4746$

$\operatorname{ISSN}(p): 2311-7435$

DOI: 10.18488/63.v10i1.2913

(C) 2022 Conscientia Beam. All Rights Reserved.

check for
updates

\title{
A STRATEGY TO STRENGTHEN AND ENHANCE THE TELECOMMUNICATION NETWORK IN SRI LANKA BY USING CONCEPTS OF GRAPH THEORY AND LINEAR PROGRAMMING MODELS
}

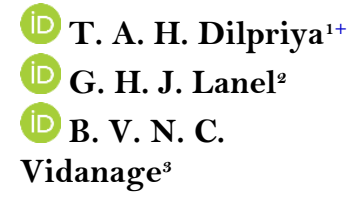

\author{
${ }^{1,2,3}$ Department of Mathematics, University of Sri Jayewardenepura, \\ Gangodawila, Nugegoda, Sri Lanka. \\ 'Email:dilzthilakarathne@gmail.com Tel: +94715640820 \\ ${ }^{2}$ Email: :hilanel@sip.ac.lk Tel: +94713063977 \\ ${ }^{s}$ Email: chathurangav7@sjp.ac.lk.Tel:+94767289809
}

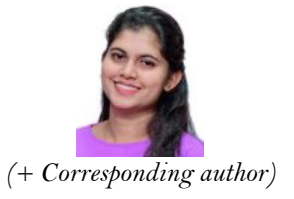

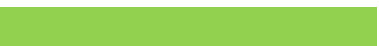

Article History

Received: 15 September 2021 Revised: 8 December 2021

Accepted: 22 December 202

Published: 27 January 2022

\section{Keywords}

Public switched telephone network

Linear simplex programs Minimum traffic flow On- net market

Cable system

Sri Lanka.

\begin{abstract}
The telecommunication sector in Sri Lanka is one of the most dynamic sectors, contributing significantly, both directly and indirectly, to investment, employment, productivity, and overall economic growth. According to the transformation of the telecommunication network of Sri Lanka, this study proposes a structure to increase the average upload and download speeds by using some concepts in pure Mathematics. The research design has aligned into two categories as interpretation and optimization. They established by using the concept of Graph Theory and linear programming models respective. We forecast the public switched telephone network (PSTN) model for the local network. Then we ranked carrier systems of Sri Lanka according to their services without violating privacy. Next, we created the minimum traffic flow, local model, based on the traffic flows. Then we proposed cable systems around Sri Lanka. After that, we calculated the required signal towers for the uniform coverage by considering the population density. Linear programming models had generated to optimize the traffic flows. We could obtain six hundred twenty-five linear programming models due to different coefficients in each case. So, we have separated those models into three sectors: low, moderate, and high. Three examples had discussed by considering them. The solutions had evaluated by using the PHP Simplex calculator.
\end{abstract}

Contribution/Originality: This study is one of the very few studies that have investigated Sri Lankan telecommunication networks. None of them came even up to this extend. This study is the first study that used linear programming and Graph Theory concepts for local telecommunication systems. One can further improve these findings to implement practically.

\section{INTRODUCTION}

How important is telecommunications as an industry? How important is telecommunications research on the overall strength of that industry [1]?

The telecommunications industry remains a significant precinct in the development approach of Sri Lanka [2]. The development strategies of Sri Lanka 'Regaining Sri Lanka- December 2002' firstly mentioned the 'telecommunications and IT sectors among the seven priority sectors. The strength of the telecommunication network of Sri Lanka was significant since the increment of the annual growth rate of the industry. It has been two to seven percent since 2002. The quality of a telecommunication network depends on the average upload and 
download speeds. Also, Sri Lanka ranked $129^{\text {th }}$ in the world for mobile and $126^{\text {th }}$ for fixed broadband. Traffic flows within the country were one of the main reasons for minimum speeds. South Korea ranked $1^{\text {st }}$ for mobile by considering the speed test rankings. Singapore ranked $1^{\text {st }}$ for fixed broadband. They were in higher rank with high traffic flows than Sri Lanka. Anyhow they maintained their quality of the internet with those barriers of traffic flows. Not only that but also Sri Lanka had more locational benefits than South Korea and Singapore. That was the fact we had to consider. The coverage area of Sri Lanka only centered at Colombo, Kandy, and a little bit of Hambantota. So our goal is to give unique coverage at low costs. Here we used Graph Theory and Operational Research knowledge to develop models to obtain the low traffic flows and low cost to upgrade local telecommunication networks in Sri Lanka [3].

\section{LITERATURE REVIEW}

This section describes variables and highlights the significant findings of previous research studies. The relationship between customer and service is called customer satisfaction. It is an area of study. This section will also focus on the corporate image, marketing mix elements of telecom service, especially pricing or telecom tariff structures, customer service, value-added service, and the marketing techniques of service providers. This research base theoretical facts of Graph theory and linear programming models. They are used to remodel the telecommunication network. There is a discussion of the gap between previous studies.

Haddad, Laugier, and Maurras had presented two models for telecommunication network design [1]. They provided point-to-point traffic demands as well as topology (2000). Haddad, Laugier, and Maurras built a continual cost capacity function for every link. The price capacity function assisted in seeking out the minimum cost capacity to satisfy the given demands. Haddad reused the freed resources for re-routing traffic [1]. He identified that every interrupt demand was re-routed between its origin and destination when a link failed (2000). In [1], initial routing, re-routing, and global capacity had optimized simultaneously. They want to evaluate capacity and routing in telecommunication networks under survivability constraints.

Novak [2] found some results of contemporary telecommunication technology within the Aeronautical Telecommunication Network (ATN). The ATN was an information communications network [2]. It provided an air/ground and ground/ground communications service. Novak deals with a combination of contemporary telecommunication technology into the developing sector of aeronautical telecommunication. Novak summarized the fashionable telecommunication networks within the aeronautical telecommunication network [2].

Ashrafuzzaman, et al. [3] said telemedicine uses information and communication technology to help with medical information and services [3]. Telemedicine is transmitted using pictures, voice, and other data over large distances. Ashrafuzzaman, et al. [3] tried to introduce telemedicine in Bangladesh. Because of technical limitations and, as a result, the inability to meet the community at a low cost, none of them had been commercially successful (2009). They proposed a telemedicine specification using the present fiber-optic backbone of Bangladesh [3]. This architecture had connected with Wireless Body Area Networks (WBANs).

The unfair competition between regulated and unregulated VoIP providers had discussed in Haryadi and Niramaya [4]. Haryadi and Niramaya were concerned about the IP network in Indonesia. There were only a few Internet Protocol (IP) networks in Indonesia (2014). Haryadi and Niramaya estimated that over five years from 2014, there was a mixture of non-IP networks and IP networks. The worldwide VoIP service had categorized as the regulated and unregulated providers in Indonesia [4]. The unregulated service had defined as a service outside the regulated one. It had broadly referred to as the over-the-top (OTT) service. There had been several differences between regulated and unregulated providers in areas: infrastructure, traffic, rates, and service quality [4].

Valdar [5] wrote a book that supported understanding telecommunications networks [5]. He included the concept of public switched telephone networks (PSTN) [5]. Valdar explained all the interlinks between other telecommunication networks. It noted that each of the three networks use essentially gets the identical form of the 
switching system. The mobile networks used radio links. Valdar managed the fixed wire access of the PSTN and cable TV networks. It was required to interconnect these networks forms to networks in other countries, as described in Valdar [5]. They also introduced the concept of the net and the way subscribers gain access to it via the PSTN, cable modems, over cable TV networks, xDSL broadband, mobile networks, or over leased lines using fiber. The various networks related to a PSTN Telco had introduced at the end [5].

Supply chains involve repair operations in equipment-intensive service industries Liret, et al. [6]. Liret, et al. [6] are concerned about tactical inventory planning with optimally planned supplies and repairs supporting demand forecasts. They introduced a model that is open to a spread of network topologies, site functions, and transfer policies [6].

Communication must have stability, economization, high bandwidth, and security [7]. Mobile technologies have their benefits and downsides, but they are necessary for modern working media. Because of their ingenuity, they provide a wide range of advantages but also include significant risks. Toro considered both the benefits and downsides of mobile technology (2020). The advantages of using mobile technologies for business include increased individual efficiency and productivity, improved service quality and flexibility, the ability to accept payments wirelessly, increased ability to speak in and out of the workplace, greater access to modern applications and services, and improved networking capabilities [7]. The most common disadvantage occurred while using mobile technologies in business are costs. New devices and technologies are expensive to accumulate and need maintenance and maintenance. Workplace distractions could increase [7].

Zhukov, et al. [8] discussed telecommunication networks of assorted topologies [8]. They defined the operational readiness coefficient. Also, Zhukov, et al. [8] analyzed the operational readiness of telecommunication networks [8].

Vishnevsky and Semenova applied polling systems to telecommunication networks (2021). Stochastic polling models have been used successfully in the performance evaluation design. Also, it performed in optimization of telecommunication systems and networks, transportation system, road management systems, traffic, production systems, and inventory management systems [9]. Vishnevsky and Semenova discussed the results for two-queue systems as a case of polling systems. They present the results concerning the specifics of polling models: a polling order, service disciplines, methods to queue or group arriving customers, and feedback in polling systems [9].

Savkin, et al. [10] are concerned about wireless communication networks. Un-manned aerial vehicles (UAVs) had adopted to boost the pliability and robustness of wireless communications networks [10]. The reconfigurable intelligent surface (RIS) technology has been given increasing attention to improving the throughput of fifthgeneration $(5 \mathrm{G})$ millimeter-wave (mmWave) wireless communication.

Coudert and Munoz [11] predicted an outline for various aspects of graph theory in Coudert and Munoz [11], Coudert, et al. [12]. They applied those aspects to communication engineering. Coudert and Munoz cope with network topologies, resource competition, state transition diagrams, and specific models for optical networks. They proposed the Optical Transpose Interconnection Systems (OITS) architecture [12].

Graph theory results applied to problems in communications. For example, the node coloring problem had applied to the channel assignment problem in cellular mobile communication systems. Tamura, et al. [13] applied graph theory to problems in communication systems [13].

The telecommunication network had applied to discrete mathematics Rosen [14]. Rosen [14] explained the connectivity of telecommunication networks using discrete mathematics. Singhrova and Deswal [15] explored the usage of graphs for modeling communication networks [15]. They represented the communication networks as a binary tree, 2-D array, and butterfly network (2012). Bonin, Docemmilli, and Webb reviewed some of the applications of graph theory in network security (2015). They covered some algorithmic aspects and presented network coding and its relation to routing in Docemmilli, et al. [16]. Traffic flow was a serious factor that affected low speeds in telecommunication networks. The traffic flow concept of telecommunication networks followed the 
junction traffic flow concept. Batugedara and Lanel [17] optimized the traffic signaling systems by reducing the cycle time. That could be used in telecommunication networks directly [17]. Also, Thathsarani and Lanel [18] proposed a model to minimize traffic congestion [18]. It helped to identify critical points. Critical points had used to recognize some nodes in telecommunication networks. Simic, et al. [19] analyzed social networks [19]. They used churn prediction results on social networks. Prytz [20] had given an optimization model for capacity dimensioning of multicast-enabled backbone communication networks. A Lagrangian decomposition branch and the bound scheme proposed in Prytz [20]. Network design and network synthesis have been the classical optimization problem in telecommunication for a long time. Hoesel [21] gave an overview of the developments by solving classical and modern telecom optimization problems [21]. He used classical results such as Menger's disjoint paths theorem and Ford Fulkerson's max-flow min-cut theorem. Srikant and Shakkottai [22] studied protocol design for various functionalities within communication network architecture [22]. It had viewed as a distributed resource allocation problem. The global scenario of mobile telecommunications networks suggested that the total number of mobile users would continue growing as the service demand within the next years [23]. The growth was expected mainly in Asiatic and developing countries [23]. Lanel and Perera presented the model to optimize course time tables using graph theory coloring and integer linear programming (2016). The system used an Integer Linear Programming model in Lanel and Perera [24]; Lanel, et al. [25]. A mobile communication network optimization system had predicted by Duan and Luo [26]. That system had based on artificial intelligence technology [26]. Also, Chimmanee and Jantavongso [27] found practical mobile network planning and Thai cities. It supported stakeholders, policymakers, and decision-makers in telecommunication policies [27].

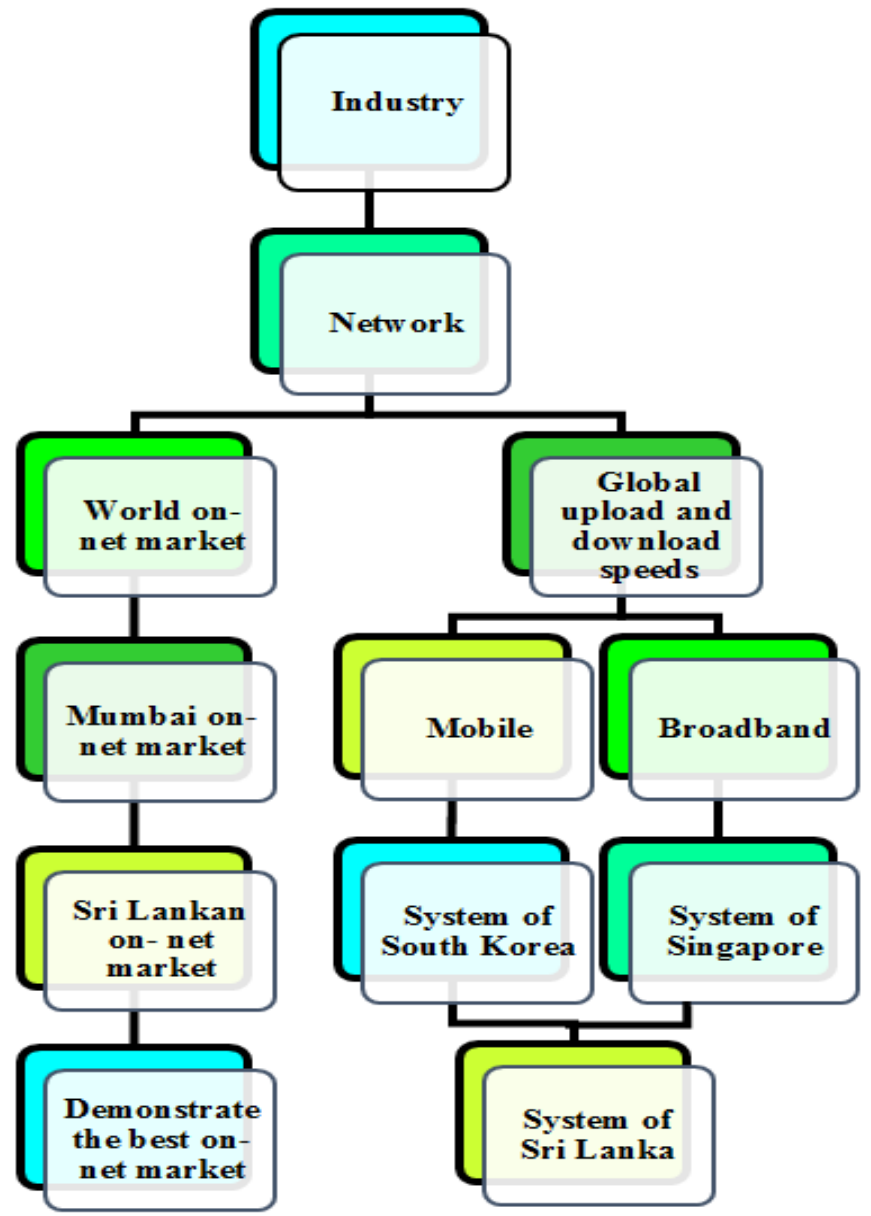

Figure 1. Interpretation protocol of research design. 


\section{RESEARCH DESIGN}

Literature showed that the telecommunication network is an updating system. We hope to fill the gap between literature and existing concepts. The telecommunication industry of Sri Lanka started on a small basis, has shown significant growth in recent years. Sri Lankan telecommunication sector liberalized in 1991. It advanced with its part-privatized in 1997 (Sri Lanka Telecommunications Research 9, 2009). The status of Sri Lanka weakened in 1996. There is a gap between this research and literature in the study area. According to the literature, the majority attempted to advance the telecommunication network using customer loyalty. The competence of accessible sources is significant as a developing country. This research had based on the modern application of graph theory and linear programming models.

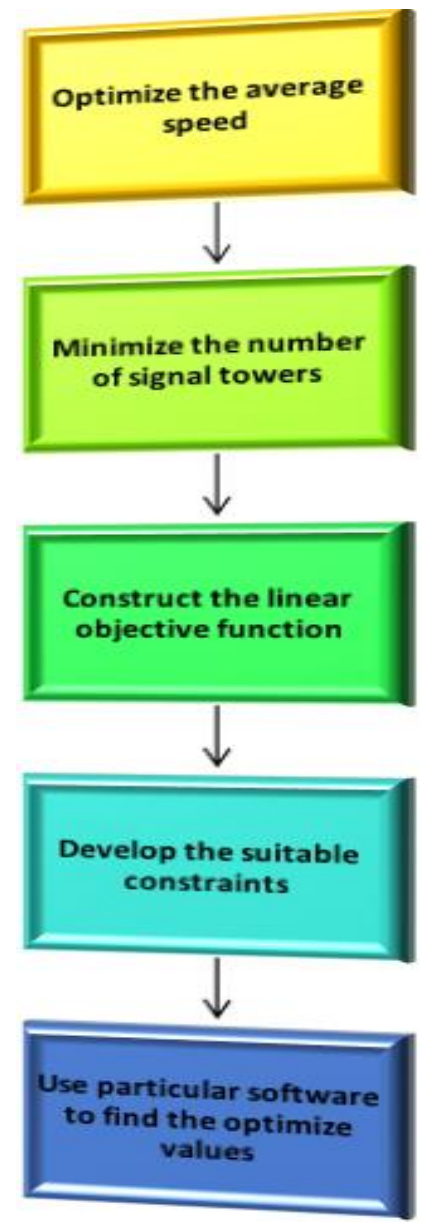

Figure 2. Optimization protocol of research design.

This research had based on two protocols. Figure 1 demonstrates the interpretation protocol. There were two sections as an on-net market and a system with high upload and download speeds. Here we used flow concepts to propose a systematic model. Figure 2 illustrates the Optimization protocol. It evaluates a linear programming model.

\section{METHODOLOGY}

The main goal was maximizing the average upload and download speeds. Also, we tried to contribute a high coverage percentage. We assigned a linear programming model to the local network. Here we used Graph Theory to obtain a particular network. Traffic flows helped to archetypal the best variety of networks. Also, we compared traffic flows concerning South Korea and Singapore. The optimization part had done by using available data. 


\subsection{Plan of the PSTN Model}

Let us discuss the stages of planning a PSTN by considering a small hypothetical island with population distribution. We determined the number of exchanges to serve the island and its catchment areas as the first step. The next stage was the process of identification of the exchange locations. The locations needed to be as close as possible to the center of gravity of these catchment areas to serve all potential customers with minimum total subscriber-line costs. Next, we estimated the traffic flows between each of the exchanges, in both directions, as set out in the matrix. After that, we applied the direct versus tandem calculation to all the traffic flows. Next, we considered the transmission network. One of the simple examples was a cable route following the single main road on the island. After that, we mapped the traffic network to the physical cable infrastructure. The latter was known as the engineering route. Finally, the dimensions of the cable and engineering routes were determined by summing all the traffic routes over each transmission link.

\subsection{Coverage Area of South Korea and Singapore}

When we consider South Korea, there were three carrier systems such as South Korea- KT, SK Telecom, and $\mathrm{U}+$. South Korea- KT was supplied $5 \mathrm{G}$ coverage around Seoul. The remains were $4 \mathrm{G}^{+}$. SK Telecom was less effective in South Korea than South Korea- KT. Also, it had centered in Seoul with a $5 \mathrm{G}$ connection. U+ coverage centered in Seoul with a $5 \mathrm{G}$ connection. The remains had covered by using $4 \mathrm{G}$ and $4 \mathrm{G}^{+}$. Singapore had the number of four carriers such as TPG mobile, SingTel mobile, mobile one, and star hub mobile. The well-known fact was the coverage of a particular area without being centered at any location as previously. SingTel mobile provided 4G+ connections throughout Singapore. Also, Mobile one coverage did not center at any location. They provided coverage to everywhere with the same connection-level $4 \mathrm{G}$. Also, star hub mobile in Singapore gave $4 \mathrm{G}+$ coverage.

\subsection{Cable System of South Korea}

The locational benefit of South Korea had lesser shown in Figure 3 than Sri Lanka. South Korea covered only three sides of the sea. The world-famous cable system in South Korea was KDD Pacific Link. KDD Pacific link went through the Yellow sea that had clearly shown in Figure 3. This cable system had mainly connected to Japan. The Russia-Japan Cable system was the famous and profitable cable system in Japan.

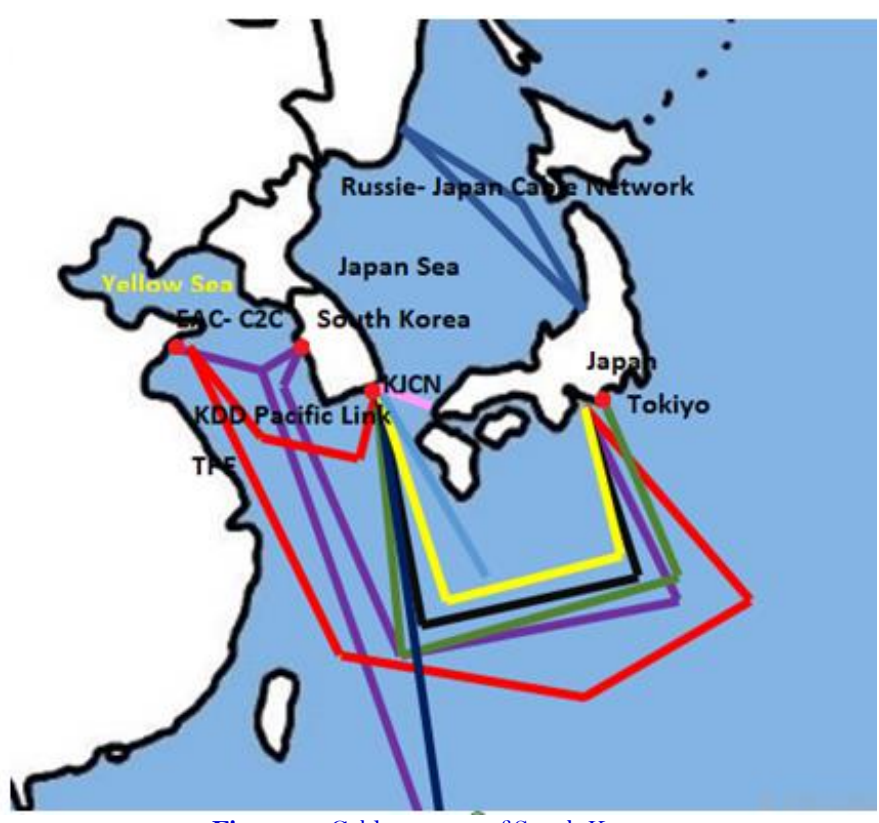

Figure 3. Cable system of South Korea. 


\subsection{Traffic Flow Calculations}

We consider the traffic flows of Sri Lanka and South Korea to further calculations. Here we had only considered districts as plantations. If data of divisional sectors is available, it will assist in finding more than we discussed here. Traffic flows had calculated by using formulas in the book understanding Telecommunications networks by Valdar [5]. Traffic flow of $A$ and $B$ plantations calculated by using,

\section{Traffic flow $=\frac{\text { Popultion of } A * \text { Popultion of } B}{(\text { Distance between } A \text { and } B)^{2}}$}

Table 1. Traffic flow table of Sri Lanka concerning each province.

\begin{tabular}{|c|c|c|c|c|}
\hline Provincial Capital & Kandy & Trincomalee & Anuradhapura & Jaffna \\
\hline \multicolumn{5}{|l|}{ Kandy } \\
\hline Trincomalee & 163279241 & & & \\
\hline Anuradhapura & 234530729 & 223509102 & & \\
\hline Jaffna & 37020177 & 51633730 & 56831970 & \\
\hline Kurunegala & 4393553359 & 156503757 & 343711517 & 42372786 \\
\hline Ratnapura & 920326533 & 56800441 & 72298636 & 18319096 \\
\hline Galle & 291743554 & 41729631 & 47805603 & 16135738 \\
\hline Badulla & 1006987069 & 62583545 & 58937402 & 13316038 \\
\hline Colombo & 1620144957 & 160922142 & 264573047 & 67287920 \\
\hline Provincial Capital & Kurunegala & Ratnapura & Galle & Badulla \\
\hline \multicolumn{5}{|l|}{ Kandy } \\
\hline \multicolumn{5}{|l|}{ Trincomalee } \\
\hline \multicolumn{5}{|l|}{ Anuradhapura } \\
\hline \multicolumn{5}{|l|}{ Jaffna } \\
\hline \multicolumn{5}{|l|}{ Kurunegala } \\
\hline Ratnapura & 561517798 & & & \\
\hline Galle & 223111703 & 861524857 & & \\
\hline Badulla & 339873225 & 385400084 & 157965255 & \\
\hline Colombo & 1966809670 & 2442641633 & 1243396148 & 416159858 \\
\hline
\end{tabular}

Table 1 indicates the traffic flows between each province in Sri Lanka. Green color cells showed the empty. Blue, yellow and colorless cells represented the high, moderate, and low traffic flows. We directly used Table 1 to obtain the minimum traffic flow model.

Table 2. Traffic flow table of South Korea concerning each province.

\begin{tabular}{l|c|c|c|c}
\hline Provincial Capital & Cheongju & Hongseong & Chuncheon & Suwon \\
\hline Cheongju & & & & \\
\hline Hongseong & 603041253 & & & \\
\hline Chuncheon & 126280460 & 108259181 & 1291981686 & \\
\hline Suwon & 2790867858 & 382616323 & 146924701 & 1142568401 \\
\hline Andong & 361799786 & 167317219 & 57360061 & 571599389 \\
\hline Changwon & 160667305 & 131564708 & 53422177 & 864466058 \\
\hline Jeonju & 327421430 & 432901510 & 25968151 & 6676095278 \\
\hline Muan & 110772619 & 126183173 & 3651985 & 40621118 \\
\hline Jeju & 7200994 & 10295559 & Jeonju & Muan \\
\hline Provincial Capital & Andong & Changwon & & \\
\hline Cheongju & & & & \\
\hline Hongseong & & & & \\
\hline Chuncheon & & & & \\
\hline Suwon & 10260920 & 26270821 & & \\
\hline Andong & 192730275 & 292887491 & & 43209151 \\
\hline Changwon & 353894902 & 163060012 & & \\
\hline Jeonju & & & & \\
\hline Muan & & & & \\
\hline Jeju & & & & \\
\hline
\end{tabular}


Table 2 indicates the traffic flows between each province in South Korea. Green color cells showed the empty. Blue, yellow, and colorless cells represented the high, moderate, and low traffic flows.

\subsection{Number of Exchanges Calculations for Population Density}

We predicted the number of exchanges concerning population density.

Table 3. Traffic flow table of Sri Lanka for some district.

\begin{tabular}{|c|c|c|c|c|c|c|}
\hline & District & 1 & 2 & 3 & 4 & 5 \\
\hline 1 & Ampara & & & & & \\
\hline 2 & Anuradhapura & 16649348 & & & & \\
\hline 3 & Badulla & 91243141 & 24626777 & & & \\
\hline 4 & Batticaloa & 145258919 & 17964850 & 36138629 & & \\
\hline 5 & Colombo & 35889234 & 68455391 & 106824670 & 24726328 & \\
\hline 6 & Galle & 15361445 & 13706996 & 44589660 & 9089260 & 220538313 \\
\hline 7 & Gampaha & 43025098 & 89552874 & 135876512 & 30016989 & 926061814 \\
\hline 8 & Hambantota & 18753113 & 7497367 & 51736016 & 8740902 & 49667412 \\
\hline 9 & Jaffna & 4328608 & 25520545 & 5514217 & 4460904 & 17430283 \\
\hline 10 & Kalutara & 18935496 & 24937941 & 60157075 & 12108598 & 162583331 \\
\hline 11 & Kandy & 68225419 & 80863183 & 335476699 & 44991628 & 345938665 \\
\hline 12 & Kegalle & 24980033 & 43444833 & 95207855 & 17312899 & 446809851 \\
\hline 13 & Kilinochchi & 974431 & 7170308 & 1184088 & 1068839 & 3318999 \\
\hline 14 & Kurunegala & 49265971 & 146809840 & 147752448 & 37925156 & 530441303 \\
\hline 15 & Mannar & 869591 & 10527680 & 1233554 & 877823 & 4494105 \\
\hline 16 & Matale & 22823251 & 40449266 & 75927604 & 17120917 & 102396911 \\
\hline 17 & Matara & 13984599 & 9647536 & 40151386 & 7744943 & 105483024 \\
\hline 18 & Monaragala & 85931120 & 10084737 & 287426497 & 22578014 & 37781779 \\
\hline 19 & Nuwara Eliya & 41442861 & 23886509 & 59834929 & 21293488 & 158068891 \\
\hline 20 & Polonnaruwa & 25830698 & 50713922 & 29346147 & 35501388 & 31815777 \\
\hline 21 & Puttalam & 10125447 & 114963202 & 19213397 & 9023823 & 117728260 \\
\hline 22 & Ratnapura & 29082273 & 26721685 & 431699959 & 16808253 & 561944685 \\
\hline 23 & Trincomalee & 10735811 & 37428142 & 9721745 & 17080130 & 15516730 \\
\hline \multirow[t]{2}{*}{24} & Vavuniya & 5455237 & 155905439 & 6987856 & 6239480 & 18373366 \\
\hline & District & 6 & 7 & 8 & 9 & 10 \\
\hline 1 & Ampara & & & & & \\
\hline 2 & Anuradha & & & & & \\
\hline 3 & Badulla & & & & & \\
\hline 4 & Batticaloa & & & & & \\
\hline 5 & Colombo & & & & & \\
\hline 6 & Galle & & & & & \\
\hline 7 & Gampaha & 175100652 & & & & \\
\hline 8 & Hambantota & 62712752 & 50483961 & & & \\
\hline 9 & Jaffna & 4550346 & 19509185 & 2425628 & & \\
\hline 10 & Kalutara & 312661235 & 847007037 & 38531867 & 7157221 & \\
\hline 11 & Kandy & 68064178 & 569919389 & 40675842 & 12805644 & 139983246 \\
\hline 12 & Kegalle & 49587281 & 112515471 & 21347568 & 7919982 & 140046543 \\
\hline 13 & Kilinochchi & 860652 & 3822095 & 482053 & 28025678 & 1359292 \\
\hline 14 & Kurunegala & 66454690 & 102892980 & 31897795 & 18574144 & 160581523 \\
\hline 15 & Mannar & 987398 & 5219362 & 496364 & 11077743 & 1700992 \\
\hline 16 & Matale & 18957963 & 167487606 & 11202261 & 5221308 & 38548083 \\
\hline 17 & Matara & 581215431 & 93959580 & 110373393 & 3232947 & 110217585 \\
\hline 18 & Monaragala & 19777189 & 44741761 & 35037130 & 2620411 & 22302753 \\
\hline 19 & Nuwara Eliya & 52732549 & 215997527 & 40210201 & 5060624 & 87537509 \\
\hline 20 & Polonnaruwa & 8238142 & 42415782 & 5884844 & 5616017 & 13388819 \\
\hline 21 & Puttalam & 15995414 & 154066797 & 6867410 & 15854023 & 34836359 \\
\hline 22 & Ratnapura & 215245385 & 611697977 & 62911670 & 6722648 & 540572449 \\
\hline 23 & Trincomalee & 4390278 & 18997486 & 3014705 & 7866251 & 6673383 \\
\hline 24 & Vavuniya & 38871999 & 22548082 & 2400376 & 18903213 & 7144497 \\
\hline
\end{tabular}


Table 3 indicates the traffic flows between some districts in Sri Lanka. This table was an extended version of Table 1. Blue color cells represent the empty. Colorless cells represent the traffic flows in between a particular column district and row district. We directly used Table 3 to obtain the minimum traffic flow model. If we can use the values of divisional sectors rather than district values, it will give more results than we discussed here. The highest traffic flow indicates between the Colombo and Gampaha districts.

Figure 4 had obtained by using Table 3 and called the local plants model. Here we estimated the required exchanges by considering the population density. According to the calculations, about one hundred plants had required for this model. The highest number of local plants required was the Colombo district. It was twenty-eight. The lowest number of local plants required was Mannar. It was zero.

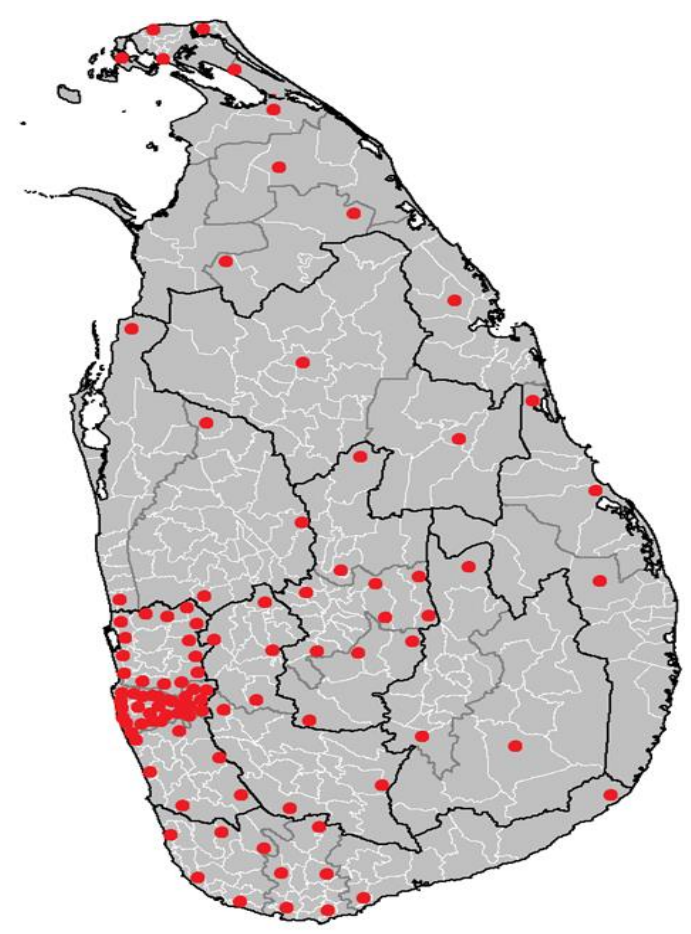

Figure 4. Local plants model.

\subsection{Optimization Model}

The optimization model had based on the concept of a general edge-based flow model. The idea of general edge-based flow model was taken by Rosen [14].

General Edge-Based Flow Model [GM: EF $] \mathrm{S}$

Minimize

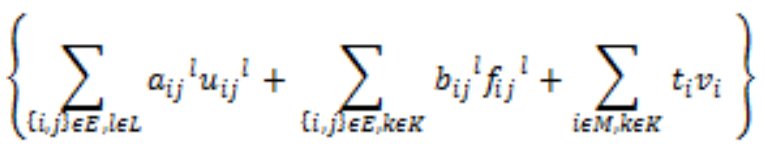

Subject to:

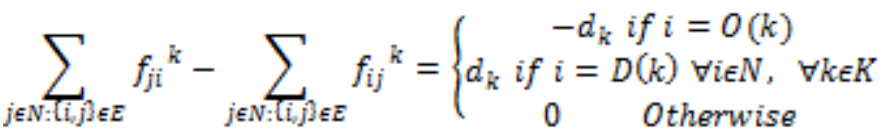

$\sum_{k \in K} f_{i j}^{k} \leq \sum_{i \in L} C_{\mathbb{l}} u_{i j}^{\mathbb{N}} \forall\left\{i_{i} j\right\} \in E$ 


$$
\begin{aligned}
& \sum_{k \in E} f_{i j}{ }^{k} \leq \sum_{\mathbb{i} \in L} C_{i} u_{i j}{ }^{\mathbb{I}} \quad \forall\left\{i_{s} j\right\} \in E \\
& \sum_{k \in K} \sum_{j \in \mathbb{N}:\left\{i_{j} j \in E\right.} f_{i j}^{k} \leq T v_{i} \quad \forall i \in M
\end{aligned}
$$

$u^{\mathbb{1}} \in U^{\mathbb{1}} \quad \forall l \in L$

$f_{i j}^{k} \geq 0 \quad \forall\{i, j\} \in E, \forall k e K$

$0 \leq u_{i j}^{\mathbb{d}} \leq \mu_{i j}^{\mathbb{R}}$ and integer $\forall\{i, j\} e E, \forall l e L$

$v_{i}=0$ or 1 VieM

$a_{i j}^{l}$ - Distance between origin node to nearest submarine plant.

$b_{i j}{ }^{l}-$ (Traffic flow between origin node to nearest submarine plant)/ (Traffic flow between particular submarine plant to a destination point).

$t_{i j}^{l}$ - Cost value for connection facility from the origin node to destination node.

\section{DATA ANALYSIS AND FINDINGS}

\subsection{Plan of the Local PSTN Model}

Here four stages had created to model the local PSTN.

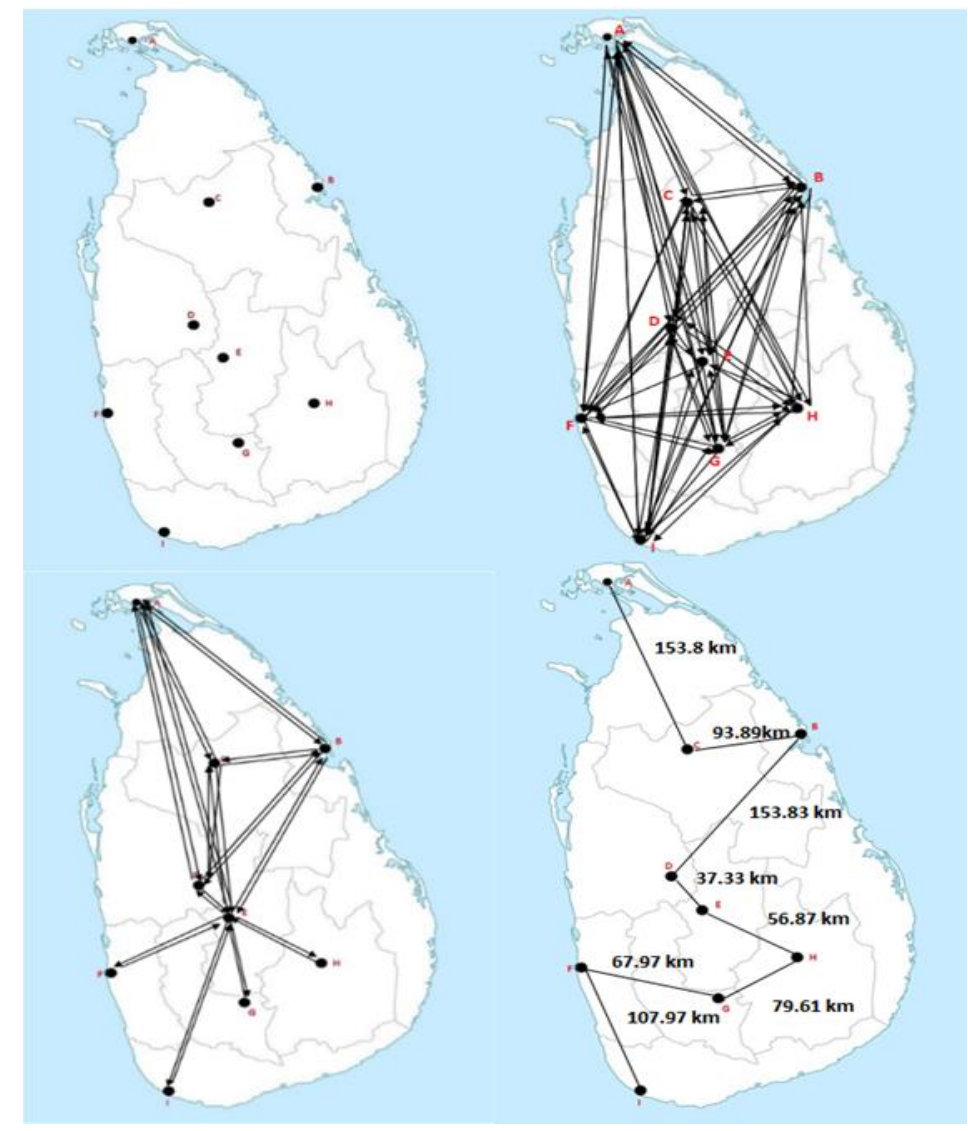

Figure 5. PSTN model stages of Sri Lanka 
The number of plants and catchment areas had identified as the first step of planning PSTN. It has shown in Figure 5. Assume that the internet plant will be in the given locations. The traffic distribution paths had shown in the second stage of Figure 5. The traffic routing matrix had used to accomplish the third stage of traffic routing. Finally, in the fourth stage, the dimensions of the cable, an engineering route, were determined by summing all the traffic routes over each transmission link.

\subsection{Coverage Area of Sri Lanka}

The geographical area had covered by the network system of the service provider. The user had the chance to complete a call using the carrier's network or a partner network within this area. Sri Lanka has five carrier systems in its telecommunication network. Each service provider symbolized by randomly using English letters without violating their privacy.

Table 4. Summary of carrier systems of Sri Lanka.

\begin{tabular}{l|c|c}
\hline Carrier & Coverage Rank & Connection Type \\
\hline $\mathrm{ABC}$ & 3 & $3 \mathrm{G}$ \\
\hline $\mathrm{DEF}$ & 2 & $3 \mathrm{G}$ \\
\hline $\mathrm{QPR}$ & 4 & $2 \mathrm{G}$ \\
\hline $\mathrm{UVW}$ & 5 & $2 \mathrm{G}$ \\
\hline $\mathrm{XYZ}$ & 1 & $4 \mathrm{G}$ \\
\hline
\end{tabular}

Table 4 indicates both coverage rank and connection type of carrier systems in Sri Lanka. It demonstrates that the best coverage percentage has carrier XYZ, and weak coverage has carrier UVW. The updated connection type should be carrier XYZ. Although it is not much updated when compared with Singapore and South Korea. All the carrier systems in Sri Lanka were only limited to Colombo.

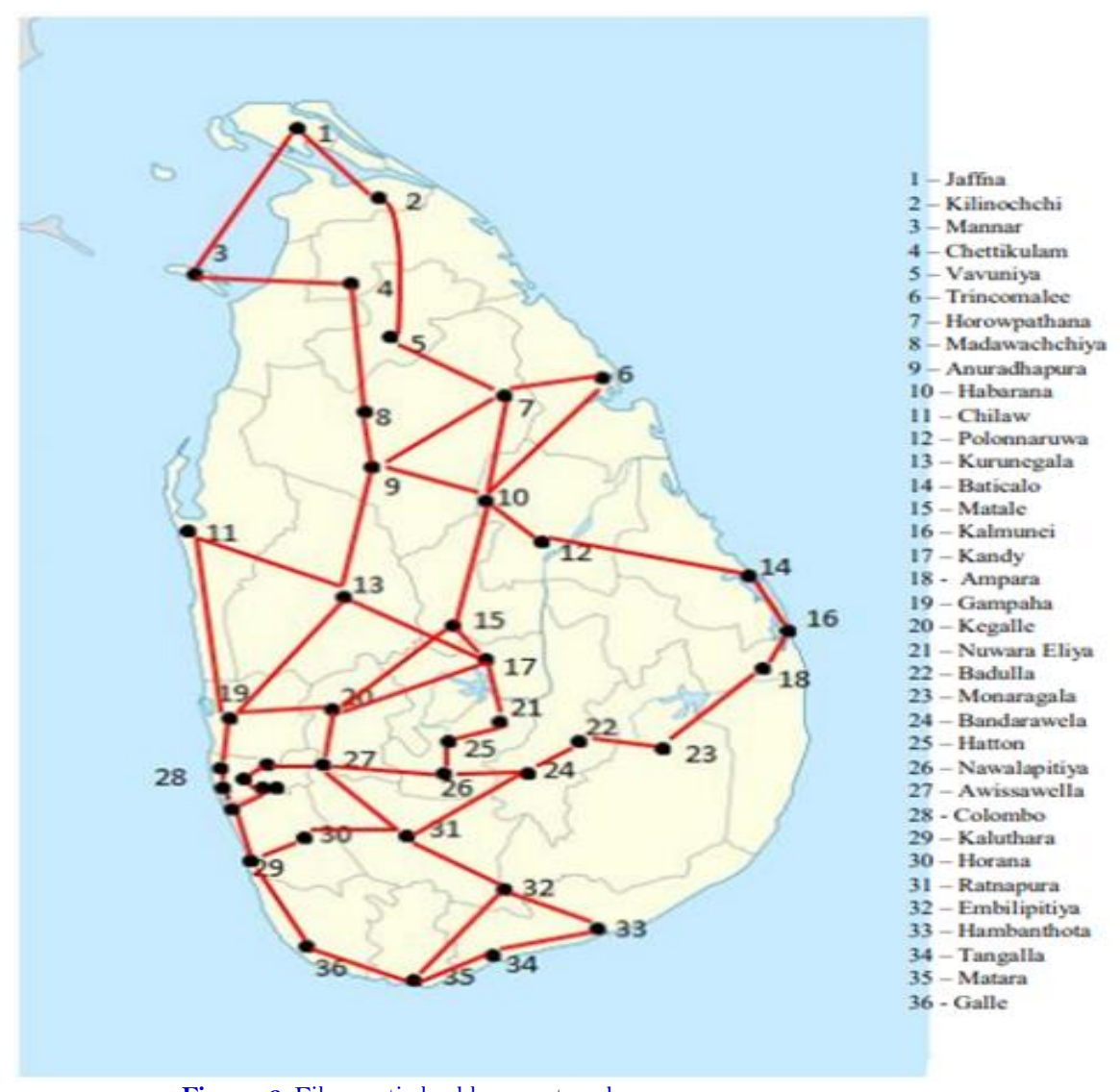

Figure 6. Fiber optic backbone network. 


\subsection{Fiber Optic Backbone Network}

The backbone or telecommunications backbone is the nerve center of a very high-speed network. The backbone uses the most efficient high-bandwidth technologies. Since the 1990s, optical fiber has become the foundation and standard for this segment of digital networks.

Figure 6 represents the fiber optic backbone network in Sri Lanka. Here thirty-six plants are situated in Sri Lanka, and nodes represented those plants. Each connected line (edge) demonstrated the fiber optic connected path. This model is available in Sri Lanka at this moment.

\subsection{Minimum Traffic Flow Local Model}

The model had established on the traffic flow concept. Nodes exemplify the highly populated divisional sectors in each district. It is conceitedly saying that this model is a hundred percent innovative one. Here the model starts with a node of Colombo, and then each edge is twisted according to the minimum traffic flows.

Figure 7 indicates the minimum traffic flows in between every two plantations. Every edge is situated in the highly populated divisional sector of each district and represents the minimum traffic flow of the nearest plant. Here Figure 7 is directly based on traffic flows and minimum distances that we described in Table 1.

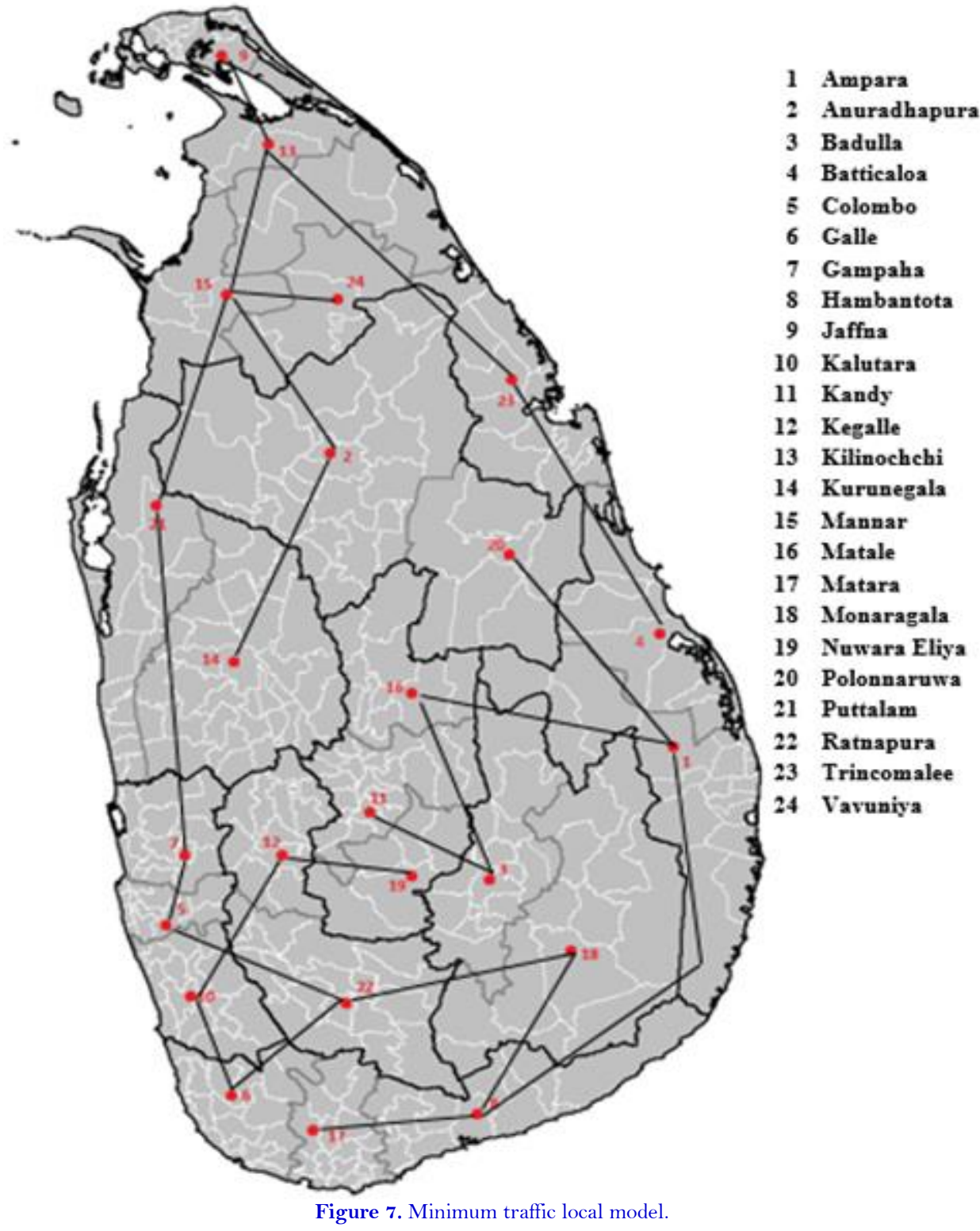




\subsection{On-Net Market around Sri Lanka}

According to Figure 8, Sri Lanka has more locational benefits than others. On net markets effortlessly can pass through around Sri Lanka. Also, Sri Lanka can earn billions of money using the Maldives Sri Lanka cable system. To get the highest income, Sri Lanka needs to give this project the best carrier performances. Also, Sri Lanka had got an internet connection through the Mumbai On-net market .

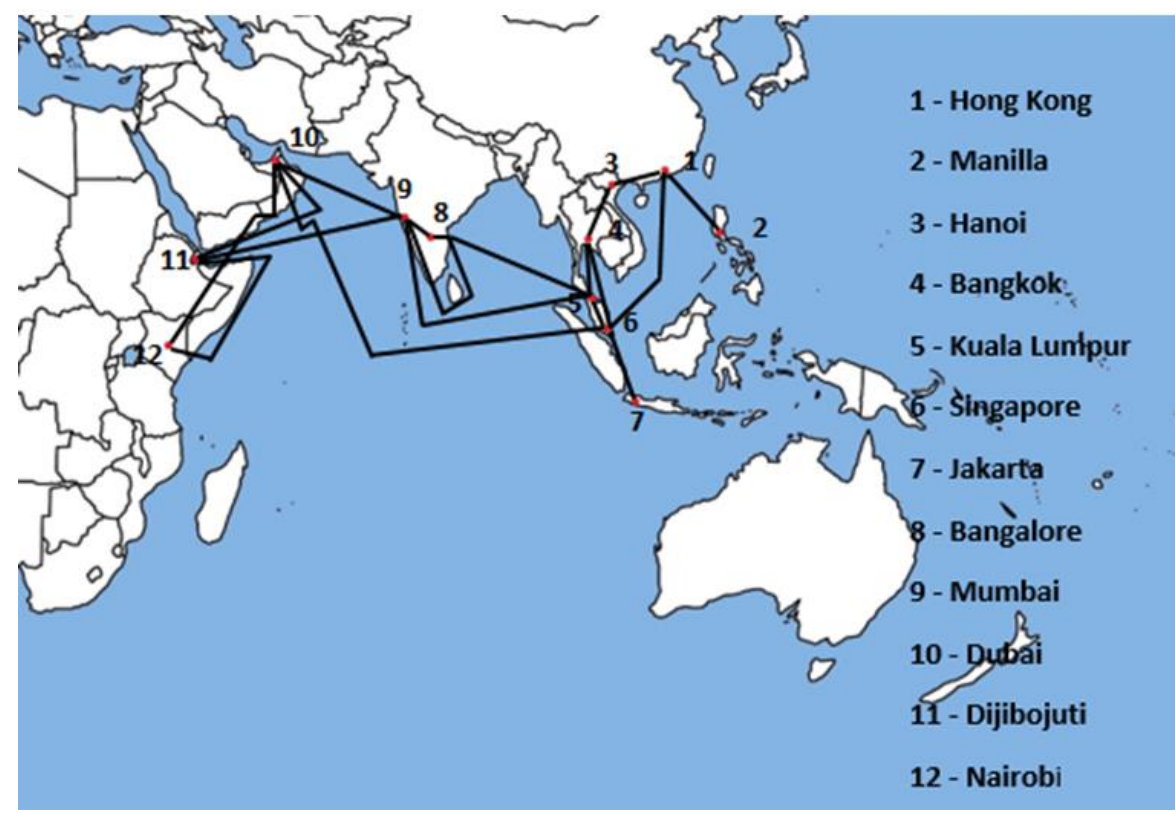

Figure 8. On-net market of Sri Lanka.

\subsubsection{Key Developments}

- Network expansion with $5 \mathrm{G}$ pre-commercial tests project is planning to conduct by Dialog Axiata and Mobitel, aiming to invest millions of rupees in network expansion.

- $\quad$ Fixed broadband penetration remains relatively low but is growing steadily.

- Maldives Sri Lanka Cable (MSC) is commissioned, expected to be lit at the end-2020.

- Telecommunication Levy is reduced to $11.25 \%$ of telecom service revenue.

- High mobile penetration leading to slow-down in market growth.

- Mobile broadband subscriber growth continuing steadily, supported by wider LTE coverage and cheaper LTE-enabled devices.

- Telco market remains resilient despite the difficult macro environment (economic crises, presidential election, and terrorist attacks).

\subsection{Cable System around Sri Lanka}

Sri Lanka has a great locational opportunity for this cable system that had shown in Figure 9. Bharat Lanka cable system is one of the famous among them. The Bharat Lanka Cable System (BLCS) is a 320km submarine cable system directly connecting India and Sri Lanka.

\subsection{Cable Landing Stations of Sri Lanka}

Sri Lanka Telecom has the following cable landing stations shown in Figure 10:

- Colombo Cable Landing Station with SMW4 and Dhiraagu-SLT cable systems.

- Mount Lavinia Cable Landing Station with SMW3 and Bharat Lanka Cable System.

- Matara Cable Landing Station with SMW5 cable system. 


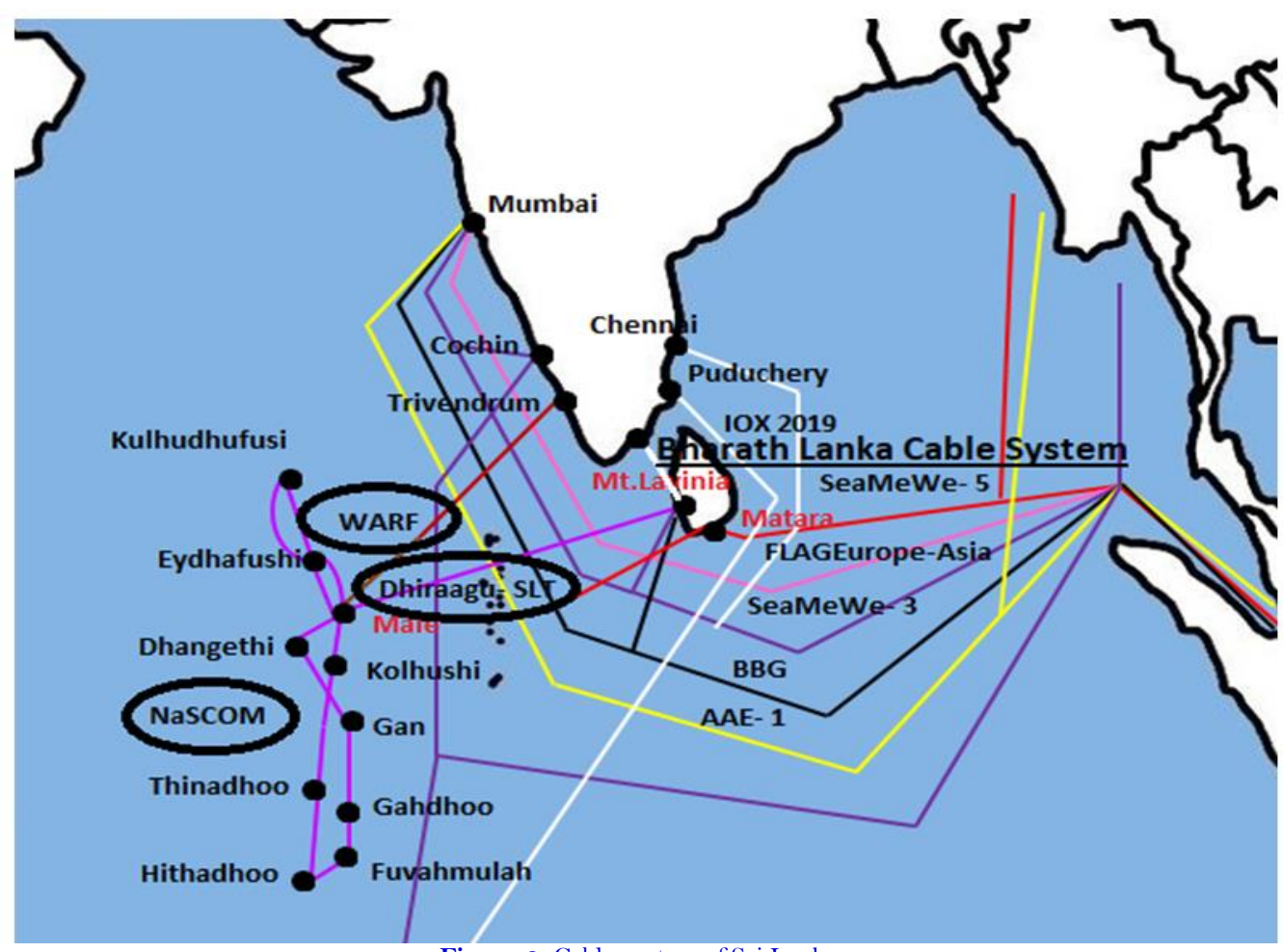

Figure 9. Cable system of Sri Lanka.

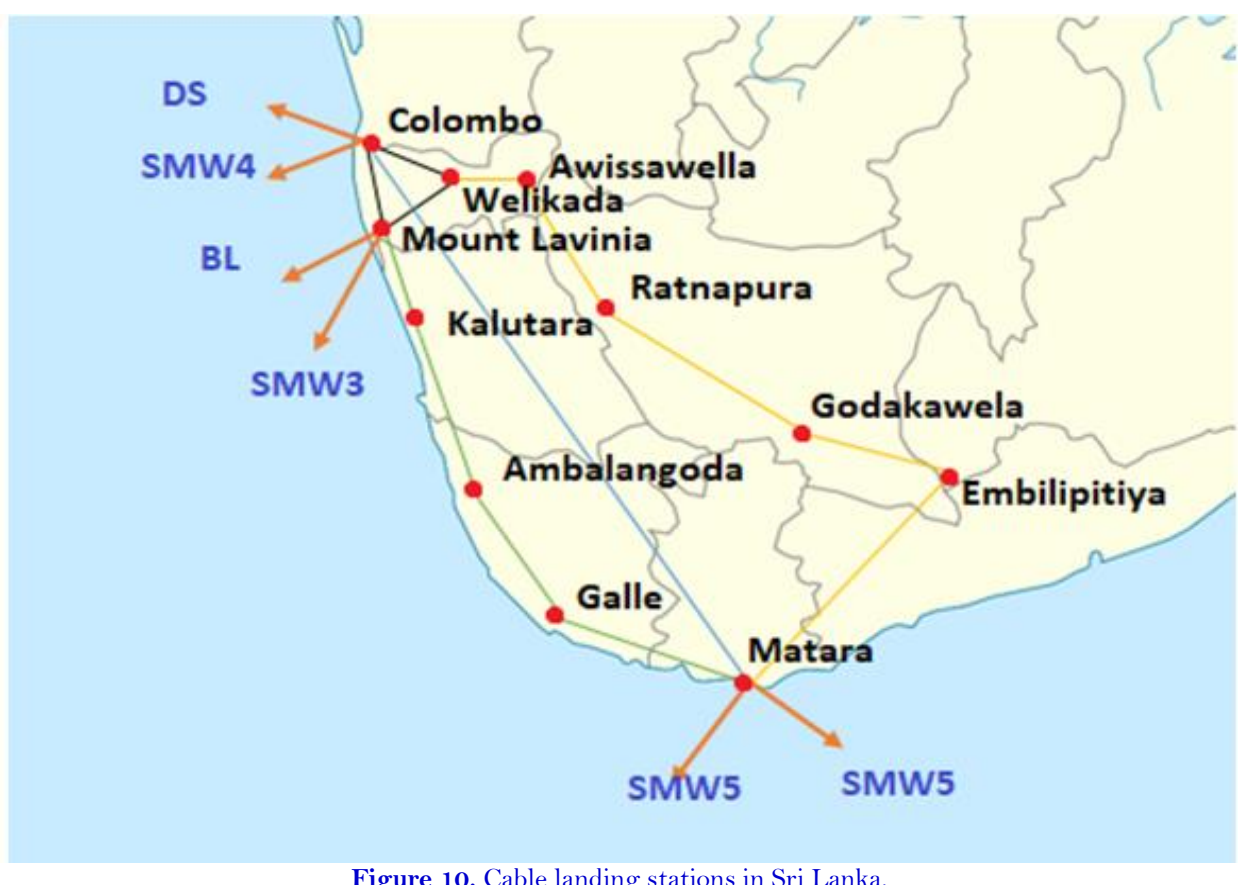

Figure 10. Cable landing stations in Sri Lanka.

\subsection{Suggestions of Signal Towers}

Highly Populated Districts.

Population Density (1000 - 3500).

Table 5 indicates the land areas of highly populated districts except for inland water areas, lowland rain forest areas, and wet monsoon areas. Table 5 assisted in identifying the required signal towers of highly populated districts.

Moderate Populated Districts.

Population Density (100 - 1000). 
Table 5. Land area of highly populated districts.

\begin{tabular}{l|c|c|c|c|c}
\hline & $\begin{array}{l}\text { Total area } \\
\left(\mathbf{k m}^{\boldsymbol{}}\right)\end{array}$ & $\begin{array}{l}\text { Inland water } \\
\text { area }\left(\mathbf{k m}^{\boldsymbol{}}\right)\end{array}$ & $\begin{array}{l}\text { Lowland rain } \\
\text { forest area }\left(\mathbf{k m}^{\boldsymbol{}}\right)\end{array}$ & $\begin{array}{l}\text { Wet monsoon } \\
\text { forests }\left(\mathbf{k m}^{\boldsymbol{}}\right)\end{array}$ & $\begin{array}{l}\text { Land Area } \\
\left(\mathbf{k m}^{\boldsymbol{q}}\right)\end{array}$ \\
\hline Colombo & 699 & 23 & 14 & - & 662 \\
\hline Gampaha & 1387 & 46 & 2 & - & 1339 \\
\hline
\end{tabular}

Table 6. Land area of moderately populated districts.

\begin{tabular}{|c|c|c|c|c|c|}
\hline & $\begin{array}{c}\text { Total area } \\
\left(\mathrm{km}^{2}\right)\end{array}$ & $\begin{array}{l}\text { Inland water } \\
\text { area }\left(\mathbf{k m}^{2}\right)\end{array}$ & $\begin{array}{l}\text { Lowland } \\
\text { rain forest } \\
\text { area }\left(\mathrm{km}^{2}\right)\end{array}$ & $\begin{array}{l}\text { Wet monsoon } \\
\text { forests }\left(\mathrm{km}^{2}\right)\end{array}$ & $\begin{array}{l}\text { Land Area } \\
\left(k m^{2}\right)\end{array}$ \\
\hline Jaffna & 1025 & 96 & - & - & 926 \\
\hline Puttalam & 3072 & 190 & - & - & 2882 \\
\hline Kurunegala & 4816 & 192 & - & 13 & 4611 \\
\hline Kalutara & 1598 & 22 & 140 & - & 1436 \\
\hline Anuradhapura & 7179 & 515 & - & - & 6664 \\
\hline Polonnaruwa & 3293 & 216 & - & 464 & 2613 \\
\hline Matale & 1993 & 41 & 82 & 311 & 1559 \\
\hline Kandy & 1940 & 23 & 141 & 35 & 1741 \\
\hline Nuwara Eliya & 1741 & 35 & 36 & 1 & 1669 \\
\hline Kegalle & 1693 & 8 & 100 & 0.4 & 1585 \\
\hline Ratnapura & 3275 & 39 & 360 & 57 & 2819 \\
\hline Trincomalee & 2727 & 198 & - & 0.04 & 2529 \\
\hline Batticaloa & 2854 & 244 & - & 134 & 2476 \\
\hline Ampara & 4415 & 193 & - & 455 & 3767 \\
\hline Badulla & 2861 & 34 & 16 & 158 & 2653 \\
\hline Hambantota & 2609 & 113 & 2 & 6 & 2488 \\
\hline Matara & 1283 & 13 & 157 & 18 & 1095 \\
\hline Galle & 1652 & 35 & 188 & - & 1429 \\
\hline
\end{tabular}

Table 6 indicates the land areas of moderately populated districts except for inland water areas, lowland rain forest areas, and wet monsoon areas. Table 6 assisted in identifying the required signal towers of moderately populated districts.

Low Populated Districts.

Population Density (000 - 100).

Table 7. Land area of low populated districts.

\begin{tabular}{|c|c|c|c|c|c|}
\hline & $\begin{array}{l}\text { Total area } \\
\left(\boldsymbol{k m}^{2}\right)\end{array}$ & $\begin{array}{l}\text { Inland water } \\
\text { area }\left(\mathrm{km}^{2}\right)\end{array}$ & $\begin{array}{l}\text { Lowland rain } \\
\text { forest area }\left(\mathrm{km}^{2}\right)\end{array}$ & $\begin{array}{l}\text { Wet monsoon } \\
\text { forests }\left(\mathrm{km}^{2}\right)\end{array}$ & $\begin{array}{l}\text { Land Area } \\
\left(k m^{Q}\right)\end{array}$ \\
\hline Kilinochchi & 1279 & 74 & - & - & 1205 \\
\hline Mullaitivu & 2617 & 202 & - & - & 2415 \\
\hline Vavuniya & 1967 & 41 & - & - & 1926 \\
\hline
\end{tabular}

Table 7 represents the land areas of low populated districts except for inland water areas, lowland rain forest areas, and wet monsoon areas. Table 7 assisted in recognizing the required signal towers of low populated districts.

Required signal towers for $25 \%$ coverage $\quad 637$

Required signal towers for $10 \%$ coverage $\quad 5720$

Required signal towers for $5 \%$ coverage $\quad 787$

Total required signal towers $\quad 7144$

Additionally, required signal towers 3644 


\subsection{Signal Towers Concerning Districts}

Table 8 represents the required signal towers of high populated districts. Here excludes the inland area, lowland area, and wet monsoon forests. Also required signal towers calculated concerning each district and assume that signal coverage is twenty-five percent.

Table 8. Signal towers for high populated districts.

\begin{tabular}{l|c|c|c|c|c|c}
\hline & $\begin{array}{l}\text { Total area } \\
\left(\mathbf{k m}^{\boldsymbol{q}}\right)\end{array}$ & $\begin{array}{l}\text { Inland water } \\
\text { area }\left(\mathbf{k m}^{\boldsymbol{q}}\right)\end{array}$ & $\begin{array}{l}\text { Lowland rain } \\
\text { forest area }\left(\mathbf{k m}^{\boldsymbol{q}}\right)\end{array}$ & $\begin{array}{l}\text { Wet monsoon } \\
\text { forests }\left(\mathbf{k m}^{\boldsymbol{q}}\right)\end{array}$ & $\begin{array}{l}\text { Land Area } \\
\left(\mathbf{k m}^{\boldsymbol{q}}\right)\end{array}$ & $\begin{array}{l}\text { Signal } \\
\text { Towers }\end{array}$ \\
\hline Colombo & 699 & 23 & 14 & - & 662 & 210 \\
\hline Gampaha & 1387 & 46 & 2 & - & 1339 & 426 \\
\hline
\end{tabular}

Table 9. Signal towers for moderately populated districts.

\begin{tabular}{|c|c|c|c|c|c|c|}
\hline & $\begin{array}{l}\text { Total area } \\
\left(\mathrm{km}^{2}\right)\end{array}$ & $\begin{array}{l}\text { Inland water } \\
\text { area }\left(\mathrm{km}^{2}\right)\end{array}$ & $\begin{array}{l}\text { Lowland rain } \\
\text { forest area }\left(\mathrm{km}^{2}\right)\end{array}$ & $\begin{array}{l}\text { Wet monsoon } \\
\text { forests }\left(\mathrm{km}^{2}\right)\end{array}$ & $\begin{array}{l}\text { Land Area } \\
\left(\mathrm{km}^{2}\right)\end{array}$ & $\begin{array}{l}\text { Signal } \\
\text { Towers }\end{array}$ \\
\hline Jaffna & 1025 & 96 & - & - & 926 & 117 \\
\hline Puttalam & 3072 & 190 & - & - & 2882 & 367 \\
\hline Kurunegala & 4816 & 192 & - & 13 & 4611 & 587 \\
\hline Kalutara & 1598 & 22 & 140 & - & 1436 & 182 \\
\hline Anuradhapura & 7179 & 515 & - & - & 6664 & 848 \\
\hline Polonnaruwa & 3293 & 216 & - & 464 & 2613 & 332 \\
\hline Matale & 1993 & 41 & 82 & 311 & 1559 & 198 \\
\hline Kandy & 1940 & 23 & 141 & 35 & 1741 & 221 \\
\hline Nuwara Eliya & 1741 & 35 & 36 & 1 & 1669 & 212 \\
\hline Kegalle & 1693 & 8 & 100 & 0.4 & 1585 & 201 \\
\hline Ratnapura & 3275 & 39 & 360 & 57 & 2819 & 359 \\
\hline Trincomalee & 2727 & 198 & - & 0.04 & 2529 & 322 \\
\hline Batticaloa & 2854 & 244 & - & 134 & 2476 & 315 \\
\hline Ampara & 4415 & 193 & - & 455 & 3767 & 479 \\
\hline Badulla & 2861 & 34 & 16 & 158 & 2653 & 337 \\
\hline Hambantota & 2609 & 113 & 2 & 6 & 2488 & 316 \\
\hline Matara & 1283 & 13 & 157 & 18 & 1095 & 139 \\
\hline
\end{tabular}

Table 9 represents the required signal towers of moderately populated districts. Here excludes the inland area, lowland area, and wet monsoon forests. Also required signal towers calculated for each district and assume that signal coverage is ten percent. The maximum number of signal towers required to the Anuradhapura district is at a moderate level.

Table 10. Signal towers for low populated districts.

\begin{tabular}{|c|c|c|c|c|c|c|}
\hline & $\begin{array}{l}\text { Total area } \\
\left(\mathrm{km}^{2}\right)\end{array}$ & $\begin{array}{l}\text { Inland water } \\
\text { area }\left(\mathrm{km}^{2}\right)\end{array}$ & $\begin{array}{l}\text { Lowland rain } \\
\text { forest area }\left(\mathrm{km}^{2}\right)\end{array}$ & $\begin{array}{l}\text { Wet monsoon } \\
\text { forests }\left(\mathrm{km}^{2}\right)\end{array}$ & $\begin{array}{l}\text { Land Area } \\
\left(\mathrm{km}^{2}\right)\end{array}$ & $\begin{array}{l}\text { Signal } \\
\text { Towers }\end{array}$ \\
\hline Kilinochchi & 1279 & 74 & - & - & 1205 & 76 \\
\hline Mannar & 1996 & 116 & - & - & 1880 & 119 \\
\hline Mullaitivu & 2617 & 202 & - & - & 2415 & 153 \\
\hline Vavuniya & 1967 & 41 & - & - & 1926 & 122 \\
\hline Monaragala & 5639 & 131 & 4 & 568 & 4936 & 314 \\
\hline
\end{tabular}

Table 10 represents the required signal towers of low populated districts. Here required signal towers are calculated by concerning each district and assuming that signal coverage is five percent. A maximum number of signal towers had required to the Monaragala district at a low level.

Required signal towers for $25 \%$ coverage Required signal towers for $10 \%$ coverage Required signal towers for $5 \%$ coverage 
Total required signal towers

Additionally, required signal towers
7134

3634.

\subsection{Optimization Model for Local Telecommunication System}

This optimization model intends to maximize the average upload and download speed. According to the classifications of this research, it had maximized by minimizing the cost value, traffic flow, number of signal towers, and time allocation. Here we use the linear simplex method to analyze those four categories. All the calculations had done by using PHP Simplex software. The objective function of this linear program contains four variables [7, 8].

$x_{1} \quad$ Air distance between an objective node to destination node.

$x_{2} \quad$ Traffic flow value in between objective node to destination node.

$X_{s} \quad$ Summation of air distance between an objective node to nearest submarine plant and air distance between nearest submarine plant to a destination node.

. $x_{*}$ Time needs to go through two signal towers.

Here we used four coefficients for objective functions that were shown below and were dependent on the situations.

a Fiber Optic cable cost per $1 \mathrm{~km}$.

$b$ The ratio of traffic flow in between origin node to submarine plant and submarine plant to a destination node.

c Number of signal towers passing through per $1 \mathrm{~km}$.

$d$ Twice the total number of signal towers passing through origin node to the destination node over average download speeds in Sri Lanka.

The following are the linear programs by considering population density.

\subsubsection{Low Population Density Example}

\section{Example 1- Monaragala to Batticola}

Origin node: Monaragala

Destination node: Batticola

Minimize $Z=11.2 x_{1}+1.605 x_{2}+3 x_{3}+3.369 x_{4}$

$x_{1}+x_{2}+x_{3}+x_{4} \geq 22578486.94$

$x_{2}+8 x_{3}+8 x_{4} \geq 22580975.13$

$4 x_{3}+x_{*} \geq 1480.07$

$x_{4} \geq 0.03$

$x_{1} \geq 102.09$

The optimal solution value is $Z=36239967.30912$ respect to;

$\begin{array}{ll}x_{i} & 102.08999999985 \\ x_{2} & 22578014.81 \\ x_{3} & 370.01 \\ x_{4} & 0.029999999795109\end{array}$

5.10.2. Moderate Population Density Example

\section{Example 2 - Kandy to Trincomalee}

Origin node: Kandy

Destination node: Trincomalee

Minimize $Z=11.2 x_{1}+22.294 x_{2}+3 x_{3}+5.143 x_{4}$

$x_{1}+x_{2}+x_{3}+x_{4} \geq 21194719.66$

$x_{2}+8 x_{3}+8 x_{4} \geq 21196896.42$

$4 x_{3}+x_{*} \geq 1332.83$

$x_{4} \geq 0.03$

$x_{1} \geq 155.85$

The optimal solution value is $Z=63585437.01429$ respect to;

$\begin{array}{ll}x_{i} & 155.850000001429 \\ x_{2} & 21194563.78 \\ x_{3} & 380.08 \\ x_{4} & 0.03000000026077\end{array}$




\subsubsection{High Population Density Example}

\section{Example 3- Gampaha to Kalutara}

Origin node: Gampaha

Destination node: Kalutara

Minimize $Z=11.2 x_{1}+5.695 x_{2}+3 x_{3}+1.894 x_{4}$

$x_{1}+x_{2}+x_{3}+x_{4} \geq 423503642.01$

$x_{2}+8 x_{3}+8 x_{4} \geq 423504044.5$

$4 x_{3}+x_{4} \geq 262.71$

$x_{4} \geq 0.03$

$x_{1} \geq 57.41$

The optimal solution value is $Z=802116432.2244$ respect to;

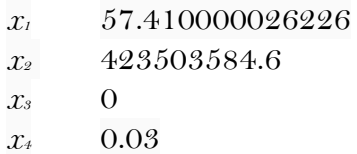

Here we considered three cases according to the population density. Air distance between an objective node to destination node was highest in moderately population density example. The summation of the air gap between an originated node to the nearest submarine plant and air distance between the nearest submarine plant to a destination node values were between 0 and 380. Traffic flow values were higher in order of high, low, and moderate examples respective. Here we consider three cases only. We have to concern about all the cases to get an overall idea.

\section{CONCLUSION}

The problem with the local telecommunication network was low average upload and download speeds compared to other countries. The main reason for that problem was traffic flow. Although other countries have higher traffic flows with high upload and download speeds than Sri Lanka. The highest download and upload speeds were maintained in South Korea from mobile and Singapore in broadband at the beginning of this study. This research aimed to develop the local telecommunication network by studying the systems in South Korea and Singapore. Here we have predicted models to solve those problems. It is required to say that all these models and calculations had done by using secondary data. All findings had based on theoretical aspects in the study. Models could be modified according to practical situations.

\section{RECOMMENDATIONS}

According to the findings that we obtained here, the carrier systems of Sri Lanka need to give unique coverage in all the areas. Also, PSTN models had to give low-cost physical cables through the country. If we have a coincidence to plant new plantations, it had to base on population quantity and minimum traffic flows. Similarly, Sri Lanka needs to take the local benefit to be its on-net market. It is essential to double the available signal towers to give required signal percentages. We can predict more reliable models by using divisional sectors. The optimization model is another concept that had to use for future research topics.

Funding: This study received no specific financial support.

Competing Interests: The authors declare that they have no competing interests.

Authors' Contributions: All authors contributed equally to the conception and design of the study.

\section{REFERENCES}

[1] A. Laugier, J. F. Maurras, and S. Haddad, "Simultaneous optimization of capacity and routing in telecommunication networks under survivability constraints," Journal of Peer Scientist, vol. 2, pp. 1-4, 2000.

[2] A. Novak, "Modern telecommunication networks in the aeronautical telecommunication network (ATN)," Aviation, vol. 10, pp. 14-17, 2006 
[3] K. Ashrafuzzaman, K. S. Kwak, M. D. H. Kabir, and M. S. Chowdhury, "A telecommunication network architecture for telemedicine in Bangladesh and its applicability," International Journal of Digital Content Technology and its Applications, vol. 3, pp. 1-11, 2009.Available at: https://doi.org/10.4156/jdcta.vol3.issue3.20.

[4] S. Haryadi and F. Niramaya, "Study of unfair competition between regulated and unregulated VoIP providers in the mixed of non and all-IP network era," 8th International Conference on Telecommunication Systems Services and Applications (TSSA), vol. 8, pp. 1-5, 2014.Available at: https://doi.org/10.1109/TSSA.2014.7065930.

[5] A. R. Valdar, "Understanding telecommunications networks (2nd ed.). Retrieved from: https://www.amazon.com/Understanding-Telecommunications-Networks-Andy-Valdar/dp/0863413625," 2017.

[6] A. Liret, C. D. C. Gilfedder, D. Lesaint, F. Lardeux, G. Owusu, and P. Desport, "A combinatorial optimization approach for closed loop supply chain inventory planning with deterministic demand," European Journal Industrial Engineering, vol. 11, pp. 303-326, 2017.

[7] T. L. Mohammed, "Evaluation of telecommunication networks. 162-165. Retrieved from: https://www.researchgate.net/publication/351423117_Evolution_of_Telecommunication_Networks," 2020.

[8] A. O. Zhukov, A. P. Pirkhavka, I. N. Kartsan, and N. M. Legki, "Analysis of the operational readiness of telecommunication networks," Journal of Physics: Conference Series, vol. 2, pp. 1-5, 2021. Available at: https://doi.org/10.1088/1742-6596/2094/3/032053.

[9] O. Semenova and V. Vishnevsky, "Polling systems and their applications to telecommunication networks," Journal of Mathematics, vol. 9, pp. 1-30, 2021 .Available at: https://doi.org/10.3390/math9020117.

[10] A. V. Savkin, H. Huang, M. Eskandari, and W. Ni, "Navigation of a UAV equipped with a reconfigurable intelligent surface for LoS wireless communication with a ground vehicle," Journal of Systems and Control, vol. 9, pp. 1-10, 2021.

[11] D. Coudert and X. Munoz, "How graph theory can help communications engineering," Broadband Optical Fiber Communications Technology (BBOFCT), pp. 1-13, 2001.

[12] D. Coudert, A. Ferreira, and X. Muñoz, "Topologies for optical interconnection networks based on the optical transpose interconnection system," Applied Optics, vol. 39, pp. 2965-2974, 2000.

[13] H. Tamura, K. Nakano, M. Sengoku, and S. Shinoda, "On applications of graph/network theory to problems in communication systems," Journal of Electronic Engineering, vol. 5, pp. 15-2 1, 2011.

[14] K. H. Rosen, "Discrete mathematics and its applications," 7th ed Boston: McGraw-Hill, 2012, pp. 1-1071.

[15] A. Singhrova and S. Deswal, "Application of graph theory in communication networks," International Journal of Application or Innovation in Engineering and Management, vol. 1, pp. 1-5, 2012.

[16] F. Docemmilli, J. Webb, and M. Bonin, "Appications in network security," presented at the Cyber Security and Digital Forensics Workshop, 2015.

[17] B. M. Y. U. A. Batugedara and G. H. J. Lanel, "Designing the traffic phases using graph colouring and book thickness to reduce the traffic for a selected junction in Colombo City," International Journal of Adavanced Research (IJAR), vol. 5, pp. 1577-1582, 2017.

[18] A. A. T. Thathsarani and G. H. J. Lanel, "A model to reduce traffic congestion in Colombo City," International Journal of Scientific and Research Publications, vol. 9, pp. 768-773, 2019.Available at: https://dx.doi.org/10.29322/IJSRP.9.06.2019.p90112.

[19] M. I. Simic, M. V. Kostic, and S. M. Kostic, "Social network analysis and churn prediction in telecommunications using graph theory," Journal of Entopy, vol. 22, pp. 1-23, 2020.Available at: https://doi.org/10.3390/e22070753.

[20] M. Prytz, "On optimization in design of telecommunications networks with multicast and unicast traffic," Doctoral Thesis-Stockholm, 2002.

[21] C. P. M. V. Hoesel, "Optimization in telecommunication networks," Maastricht University School of Business and Economics METEOR, pp. 1-28, 2004.Available at: https://doi.org/10.26481/umamet.2004045.

[22] R. Srikant and S. Shakkottai, "Network optimization and control," Foundations and Trends® in Networking, vol. 2, pp. 271-379, 2008.Available at: https://dx.doi.org/10.1561/1300000007. 
[23] A. H. Barrientos and M. E. Cortes, "Optimizing the cellular network planning process for in-building coverage using simulation," Journal of Applied Research and Technology, vol. 11, pp. 912-919, 2013.Available at: https://doi.org/10.1016/S1665-6423(13)71598-0.

[24] G. H. J. Lanel and M. T. M. Perera, "A model to optimize university course timetable using graph coloring and integer linear programming," IOSR Journal of Mathematics, vol. 12, pp. 13-18, 2016.Available at: https://doi.org/10.9790/5728-1205031318.

[25] G. H. J. Lanel, M. T. M. Perera, and P. H. H. P. N. De Silva, "Integer quadratic programming (IQP) model for cut order plan," IOSR Journal of Mathematics, vol. 13, pp. 76-80, 2017.Available at: https://doi.org/10.9790/57281302027680 .

[26] C. Duan and J. Luo, "Mobile communication network optimization based on artificial intelligence," Journal of Wireless Communication and Mobile Computing; vol. 2021, pp. 1-5, 2021.Available at: https://doi.org/10.1155/2021/9999873.

[27] K. Chimmanee and S. Jantavongso, "Practical mobile network planning and optimization for Thai smart cities: Towards a more inclusive globalization," Research in Globalization, vol. 3, pp. 1-15, 2021.Available at: https://doi.org/10.1016/j.reslo.2021.100062.

Views and opinions expressed in this article are the views and opinions of the author(s), International Journal of Natural Sciences Research shall not be responsible or answerable for any loss, damage or liability etc. caused in relation to/arising out of the use of the content. 